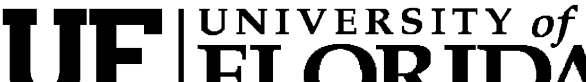 FLORIDA \\ IFAS Extension
}

\section{Growth of Generic E. coli and Aerobic Bacteria on Beef Muscle held at $50^{\circ} \mathrm{F}$ for 8 Hours ${ }^{1}$}

\author{
Larry Eubanks, Chad Carr, and Chris Pantaleo ${ }^{2}$
}

\section{Introduction}

Bacteria are everywhere in our environment. Relative to food safety and quality, the two primary kinds of bacteria which are of consequence are pathogenic bacteria and spoilage bacteria. Spoilage bacteria are generally not harmful, but they will cause food to deteriorate or lose quality by developing a bad odor or texture. Pathogenic bacteria are those such as Salmonella, E. coli O157:H7, Campylobacter jejuni, Listeria monocytogenes, and Staphylococcus aureus, all which cause food-borne illness and cannot be seen or smelled (International Commission on Microbiological Specification for Foods, 1996).

The safety of meat products is the most important parameter to consumers and the food industry alike. The two primary pathogens of concern with fresh beef are Salmonella and E. coli O157:H7. Multiple steps are taken to reduce the presence of pathogens on beef cattle at the farm (Loneragan and Brashears, 2005) at the processing plant (Koohmaraie et al., 2005; Beef Industry Food Safety Council, 2003a) and during further processing (Beef Industry Food Safety Council, 2003b; 2006). Heating beef products to $162^{\circ} \mathrm{F}$ for 16 seconds or to $135^{\circ} \mathrm{F}$ for 45 seconds will eliminate Salmonella and E. coli O157:H7 (Venkitanarayanan and Doyle, 2007). Irradiation is an effective method of eliminating pathogens; however, U.S. consumers are fearful of irradiated products (Venkitanarayanan and Doyle, 2007). Therefore, there is always an element of risk for processors of raw, ground beef products, because of the lack of a cooking step.

USDA inspected meat processing facilities try to minimize microbial growth and microbiological risk by refrigerated temperature control. However, refrigeration costs increase when processing at lower ambient temperatures. Therefore, some processors fabricate fresh meat at ambient temperature as high as $50^{\circ} \mathrm{F}$. Little documentation exists of how long fresh meat can be held at this temperature without experiencing growth of pathogenic bacteria, particularly E. coli O157:H7 and Salmonella.

The purpose of this study was to determine the growth of generic E. coli and aerobic bacteria as indicators of pathogenic bacteria on beef muscle held at $50^{\circ} \mathrm{F}$ for eight hours.

1. This document is AN222, one of a series of the Animal Sciences Department, Florida Cooperative Extension Service, Institute of Food and Agricultural Sciences, University of Florida. Original publication date November 2009. Visit the EDIS Web Site at http://edis.ifas.ufl.edu.

2. Larry Eubanks, coordinator of research programs, Department of Animal Science; Chad Carr, assistant professor, Department of Animal Sciences; Chris Pantaleo, Smithfield Food; Florida Cooperative Extension Service, Institute of Food and Agricultural Sciences, University of Florida, Gainesville, FL 32611 .

The Institute of Food and Agricultural Sciences (IFAS) is an Equal Opportunity Institution authorized to provide research, educational information and other services only to individuals and institutions that function with non-discrimination with respect to race, creed, color, religion, age, disability, sex, sexual orientation, marital status, national origin, political opinions or affiliations. U.S. Department of Agriculture, Cooperative Extension Service, University of Florida, IFAS, Florida A. \& M. University Cooperative Extension Program, and Boards of County Commissioners Cooperating. Millie Ferrer-Chancy, Interim Dean. 


\section{Experimental Procedure}

No live pathogenic bacteria were used in this study as all processes were conducted in a USDA inspected processing facility. A vacuum packaged beef inside round roast was obtained at retail, brought to the UF Meat Laboratory and held at $34^{\circ} \mathrm{F}$ until the roast was cut into $25 \mathrm{~g}$ cubes using a flame sterilized knife. After cutting, the cubes $(\mathrm{n}=7)$ were placed on a tray and held at $50^{\circ} \mathrm{F}$ for $0,2,4,5,6,7$ or 8 hours until each sample was placed in a Stomacher bag with $225 \mathrm{ml}$ of peptone water. The beef cube was massaged within the bag for one minute to incorporate the solution into the cube, then $1 \mathrm{ml}$ of the liquid was transferred to a test tube containing 9 $\mathrm{ml}$ of peptone water. The tube was vortexed, and the procedure from the initial test tube repeated on the subsequent tubes four times, resulting in five tubes containing dilutions ranging from $10-^{1}$ to $10-^{5}$.

After diluting, $1 \mathrm{~mL}$ of each dilution from the seven samples was placed on an aerobic petrifilm plate to assess aerobic plate count (APC) and an $E$. coli petrifilm plate. Three samples of each plate were generated and all plates were placed in a $95^{\circ} \mathrm{F}$ incubator for 48 hours, prior to counting. Generally, APC measures bacteria that grow in the presence of oxygen, serving as an indicator of the presence of spoilage organisms, and generic E. coli are indicators of the presence of fecal bacteria contamination. Results were reported as a logarithmic function of the colony forming units (CFU) per $g$ and analyzed using the repeated measures function of SAS (SAS Inst., Inc., Cary, NC), considering time of measurement as a fixed effect and triplicate replication as a random effect.

\section{Results and Discussion}

No E. coli was isolated from the initial product (Table 2). Accordingly, there was no difference in $E$. coli growth rate for beef held at $50^{\circ} \mathrm{F}$ up to 8 hours. For APC, 15.1 CFU were identified from the initial product (Table 2). However, the APC of beef products stored at $50^{\circ} \mathrm{F}$ did not increase $(\mathrm{P}>0.10)$ for any length of storage up to 8 hours.

This work complements the findings of other authors. Ingham et al. (2007) incorporated live pathogenic E.coli and Salmonella with various fresh meat products prior to aerobic storage at $50^{\circ} \mathrm{F}$. At that ambient temperature, pathogens were dormant or in the lag phase of growth for 22 hours (Table 3). In another study, Ingham et al. (2005) reported one $1 \mathrm{~b}$ ground beef packages thawed 9 hours at 72 or $86^{\circ} \mathrm{F}$ resulted in 0.2 and 0.5 logarithmic increases of pathogens on the product surface, respectively.

\section{Conclusion}

Most processors use $41^{\circ} \mathrm{F}$ as a critical control point for holding beef to prevent an increase in hazardous pathogen growth. This data and other supporting documentation sited in this report suggest the critical limit can be increased to $50^{\circ} \mathrm{F}$ without jeopardizing the consumer's health.

\section{Literature Cited}

Beef Industry Food Safety Council. 2003a. Best Practices for Beef Slaughter. Supported by National Meat Association, Southwest Meat Association, American Meat Institute and National Cattlemen's Beef Association. Centennial, Colo. Accessed August 4, 2009. http://nationaladmin.beef.org/CMDocs/BIFSCO/ BestPracslaught07_09.pdf

Beef Industry Food Safety Council. 2003b. Best Practices for Raw Ground Beef Products. Supported by National Meat Association, Southwest Meat Association, American Meat Institute and National Cattlemen's Beef Association. Centennial, Colo. Accessed August 4, 2009. http://www.bifsco.org/CMDocs/BIFSCO/ Best $\% 20$ Practices/groundproducts2933.pdf

Beef Industry Food Safety Council. 2006. Best Practices for Non-Intact Beef Products. Supported by National Meat Association, Southwest Meat Association, American Meat Institute and National Cattlemen's Beef Association. Centennial, Colo. Accessed August 4, 2009. http://www.bifsco.org/CMDocs/BIFSCO/ Best $\% 20$ Practices/03_29_06nonintactbestpractices.pdf

FDA. 2001. Factors that influence microbial growth. Washington D.C. Accessed August 4, 2009. http://wwwfdagov/Food/ScienceResearch/ 
ResearchAreas/SafePracticesforFoodProcesses/

ucm094145.htm

Ingham, S.C., R.K. Wadhera, M.A. Fanslau, and

D.R. Buege. 2005. Research Note: Growth of

Salmonella serovars, Escherichia coli O157:H7, and

Staphylococcus aureus during thawing of whole chicken and retail ground beef portions at 22 and $30^{\circ} \mathrm{C}$. J. Food Protection 68:1457-1461.

Ingham S.C., B.H. Ingham, D. Borneman, E. Jaussaud, E.L. Schoeller, N. Hoftiezer, L.

Schwartzburg, G.M. Burnham, and J.P. Norback. 2007. Predicting pathogen growth during short-term temperature abuse of raw pork, beef, and poultry products: use of an isothermal-based predictive tool. J. Food Protection 70:1445-1456.

International Commission on Microbiological Specification for Foods. 1996. Microorganisms in foods. Roberts, T. A., A.C. Baird-Parker, and R.B Tompkin, editors. Volume 5, Characteristics of microbial pathogens. London: Blackie Academic \& Professional. p 513.

Koohmaraie, M., T.M. Arthur, J.M. Bosilevac, M. Guerini, S.D. Shackelford, and T.L. Wheeler. 2005. Post-harvest interventions to reduce/eliminate pathogens in beef. Meat Sci. 71: 79-91.

Loneragan, G.H. and M.M. Brashears. 2005. Pre-harvest interventions to reduce carriage of $E$. coli O157 by harvest-ready feedlot cattle. Meat Sci. 71: 72-78.

Venkitanarayanan, K.S. and M. P. Doyle 2007. Foods Handbook of Nutrition and Food- Chapter 2Microbiological Safety of Food. pp 38-43. 
Table 1. Minimum, optimum, and maximum ambient temperature for pathogenic growth.

\begin{tabular}{|c|c|c|c|}
\hline & \multicolumn{3}{|c|}{ Ambient temperature $\left({ }^{\circ} \mathrm{F}\right)$} \\
\hline Organism & Minimum & Optimum & Maximum \\
\hline Campylobacter jejuni & 90 & $108-113$ & 113 \\
\hline Staphylococcus aureus & 45 & $95-104$ & 118 \\
\hline E. coli O157:H7 & 45 & $95-104$ & 115 \\
\hline Salmonella & 41 & $95-99$ & 117 \\
\hline
\end{tabular}

Table 2. Growth of generic E. coli and aerobic bacteria as indicators of pathogenic bacteria on beef muscle held at $50^{\circ} \mathrm{F}$ for eight hours.

\begin{tabular}{|c|l|l|l|l||}
\hline \hline Hour & $\begin{array}{l}\text { Colony Count for E. } \\
\text { coli (CFU/g) }\end{array}$ & $\begin{array}{l}\text { Colony count for } \\
\text { aerobic bacteria } \\
\text { (CFU/g) }\end{array}$ & $\begin{array}{l}\text { Log Difference from } \\
\text { Hour 0. }\end{array}$ & $P$-value \\
\hline 0 & 0 & 15.1 & & \\
\hline 2 & 0 & 16.2 & +0.011 & $P>0.10$ \\
\hline 4 & 0 & 21.3 & +0.062 & $P>0.10$ \\
\hline 5 & 0 & 14.5 & -0.006 & $P>0.10$ \\
\hline 6 & 0 & 18.0 & +0.029 & $P>0.10$ \\
\hline 7 & 0 & 17.9 & +0.028 & $P>0.10$ \\
\hline 8 & 0 & 16.4 & +0.013 & $P>0.10$ \\
\hline \hline
\end{tabular}

Table 3. Lag Phase Duration (LPD) and Growth Rate (GR) for Various Meat Sources Stored at $50^{\circ} \mathrm{F}$.

\begin{tabular}{|c|c|c|c|c|}
\hline & \multicolumn{2}{|c|}{ E. coli $0157: \mathrm{H7}$} & \multicolumn{2}{|c|}{ Salmonella } \\
\hline Product & LPD (hrs) & GR (log CFU/min) & LPD (hrs) & $\mathrm{GR}(\log \mathrm{CFU} / \mathrm{min})$ \\
\hline Ground Pork & 38.1 & .0004 & 54.7 & .00048 \\
\hline Ground Beef & 27.1 & .0004 & 46.4 & .0002 \\
\hline Poultry & & & 22.7 & .0004 \\
\hline
\end{tabular}

